\title{
WOMEN'S STATUS IN TUNISIA POST REVOLUTION, LEGAL ACQUIS AND REAL ACHIEVEMENTS
}

\author{
Nawel Ghali \\ ELTE Faculty of social sciences, Hungary \\ E-mail: nawelghali@yahoo.fr
}

Abstract: Under the umbrella of democratic transition, a new constitution was written which encourages more for gender equality and provides Tunisian women with further rights, mainly the political ones, to improve more the status of women within the complexity of the Tunisia society. This paper intends to focus on the Gender Gap Index, a methodological approach for the measurement of gender equality published by the World Economic Forum, to examine the regulations on women's rights in the Tunisian constitution and to connect the statistics with legal achievement in order to try to answer the main research question: to what extent laws about Tunisian women's rights are translated in practice?

Key-words: Tunisia, post-revolution, women's rights, laws, achievements

\section{Introduction}

Tunisia leads the Arab world in terms of human rights in general and women's rights in particular. Since the independence, the Tunisian government guaranteed equal rights for all Tunisians regardless their gender, race or religion. Therefore, Tunisia has faced political, social and economic changes over time which have had a deep influence on women's status in the Tunisian society. On 14 January 2011, the Tunisians were protesting on the streets, men and women, hands in hands, to put an end to the authoritarian regime of Ben Ali. Under the umbrella of the democratic transition, women gained more rights. In fact, the Tunisian society faced dramatic changes that have created new challenges for Tunisian citizens and mainly Tunisian women. Therefore, women's role during the revolution was highly appreciated by all parties and the civil society actors who welcomed the gender parity law in the constitution. However, in post revolution, gender parity law was undermined and most of leading positions are controlled by men. Even though women in Tunisia have achieved many rights, their number still represent less than men in labor force and in politics. The main concern of this article is to analyse the 
status of women in Tunisia according to four key areas which are: economic participation and opportunity, educational attainment, health and survival and political empowerment introduced by the World Economic forum with a special focus on legal text, articles in the constitution in order to answer the main research question: to what extent the laws on women's rights enforced in practice in post 2011 revolution?

\section{Theoretical framework}

Feminist theorists highlight that all that prevent women from progress, is the tradition and the custom of the society and not biological or physiological aspects. Society has a great impact on women's issues. Culturally and historically it has created a specific image for both male and female and endowed them with specific roles that gave men many privileges and advantages over the women who are treated as inferior. From childhood, both boys and girls were treated according to their biological differences which derived from the ideology that inherited from generation to another. There are different obstacles which prevent women from being equal with men on the labor market, from participating in political issues or from being decision makers in any field in many countries in the world. In fact, gender issues differ from one country to another, these differences displayed according to the country's social, economic and cultural conditions also on its applicable laws. Therefore, the image of gender identity is changing according to the time and the place. Meanwhile, the concept of gender is defined through the social roles, behaviors, and relationships between males and females. Besides, women in many countries are exposed to various forms of pressures such as ethnic, cultural, religious and other forms of discrimination (Chanter 2006, 617).

In her book Gender and power R.W. Connell (1987) states that in order to develop the theory of practice, the concept of "structure" must be edited. According to her, there is no one structure rather there are structures of substructures. More than that, she added that it is essential to differentiate between various types of structural analysis that use many notions such as the 'sexual division of labour' and "gender order" which must be changed into 'structural models" and "structural inventories". The sexual division of labor is depending on the social rules. Therefore, a specific type of work is given to a specific category of people. Some jobs are set to be for women and others for men. In labor force, the two different categories of people are provided with different payment, of course in the favor of men. Cavandish, Women on 
the line, writes "it was obvious ... "that the only qualification you need for a better job was to be a man"'”. In this context, Connell says that the sexual division of labour is reflected upon the technical division of labor to be strongly connected to each other. Furthermore, women are suffering from not only unequal pay but also from unpaid work imposed by the sexual division of labor such as housework and childcare (because of discriminatory employment and the educational and training system). Power relations serve as social structure and used as an object social practice. According to Connell, there is a difference between gender regime and gender order. Indeed, both are controlled by the state. Whereas gender regime determines the gender relation in certain institutions such as the workplace using specific regulations, gender order works on macro level of politics, it is the various relation between the gender regimes (Connell 1987, 99).

In all over the world, men have an important position in society. They enjoy a high position in different fields such as economic, political and social fields. Compare to women, men benefit from many privileges in society. Men are usually representing the dominant and the powerful individual in society and women is the subordinate who must take care of her family and made all domestic services (Ruxton 2004,8-9). The concept of 'hegemonic masculinity' is defined by Mike Donaldson (1993) as

" a culturally idealized form, it is both a personal and a collective project, and is the common sense about breadwinning and manhood. It is exclusive, anxietyprovoking, internally and hierarchically differentiated, brutal, and violent. It is pseudo-natural, tough, contradictory, crisis-prone, rich, and socially sustained. While centrally connected with the institutions of male dominance, not all men practice it. though most benefit from it. Although cross-class. it often excludes working class and black men. It is a lived experience, and an economic and cultural force, and dependent on social arrangements. It is constructed through difficult negotiation over a life-time. Fragile it may be, but it constructs the most dangerous things we live with. Resilient, it incorporates its own critiques, but it is, nonetheless, "unravelling"'”. (Donaldson 1993, 4)

'Hegemonic masculinity' constructed by the society's culture and engendered it in its institutions such as schools, media and all different public and private institutions and enterprises. In fact, if change tends to be, it should be focused not only on individuals but also on institutional transformation (Ruxton 2004, 8-9). The ideals or the heroes of a certain culture who serves as public faces are continuing to live in people's world of fantasy, they are the regulators who control the majority of male's personalities, the main argument of these figures is that; the most important is not how much 
powerful they are rather how much they could exercise the power. The men enjoy exercising this power inspired from heroes even though they are not unheroic figures, as it is beneficial for them and it provides them with a superior status. In a different context of culture and ideals, hegemonic masculinity means the practice of the structure of dominance by using the oppression tool in the gender order (Donaldson, 1993).

In recent decades, women in many countries in the world have succeeded to achieve many goals. In fact, the rate of illiteracy among women decreased. Thus, women of all ages and from all classes became present in schools, universities, workplaces. In addition to that, women also participate in parliaments and in political parties. Indeed, the concept of gender equality constructed in many societies but this harmony between men and women is relative and not widespread. Despite all progress of gender equality worldwide, gender discrimination still practiced in all countries but with different degrees (World Economic Forum 2016).

\section{Methodological approach for measurement of gender equality}

Gender equality is a goal that strongly connected with women's rights. In fact, the concept of women's human rights appeared in 1792 but a debate about women issues took place since the beginning of the fifteen century that was named by the French feminists "the querelle des femmes". Some believed that it is important to cut with the tradition of that one group exercise the others which create discrimination but other claimed that women's 'natural vocation' is being responsible of the household and taking care of children. Therefore, in the mid of the twentieth century, the United Nations was established, at that time, educated women raised and women's participation in the economic and political field increased. Due to this advance and due to women delegates "the phrase "equal rights of men and women" was inserted in the UN Charter" and the usage of "his" in many of the organization's articles changed into "everyone". Moreover, in 1979, the Commission on the Status of Women (CSW) drafted and adopted the CEDAW treaty, the Convention on the Elimination of all forms of Discrimination Against Women. They focused on the debate which took place for five centuries about the status of women and notion of equality was deeply highlighted (Fraser 1999, 857).

To measure gender equality there are many statistical tools. Accordingly, for the measurement of gender equality, inequality or gender gap specific indicators are needed. In fact, the measurement of gender index is an important means which gave a clear idea about women's situation in many countries. Therefore, these approaches analyze and evaluate gender equality 
from different perspectives. In this context, the writer Hidasi Judit states: "There are two sides of the coin: to look at the situation from "the glass half empty" perspective - that is to identify gaps or to look at the situation from "the glass half full" perspective - that is to measure gender equality" (Hidasi 2016, 10-11). Based on one approach which is gender gap index, I am going to analyse the status of women in Tunisia post-revolution.

\subsection{Gender inequality index (GII)}

The United Nations Development Programme's Human Development report measures annually gender inequality in 159 countries. It is the fifth sustainable development seventeen goals of the United Nations. Therefore, Gender Inequality Index is one of the alternatives that measuring gender inequality. The higher the gender inequality index the more the gap between men and women is larger and human development is lower. The gender inequality index measures the gender inequality based on three main elements related to human development which is the reproductive health, empowerment, and economic status. In fact, the reproductive health is measured by adolescent birth rate and maternal mortality. The empowerment is measured by the number of seats of females in the parliament and the proportion of male and female aged more than 25years old with at least some secondary education. The economic status is measured by the participation rate of male and female aged 15 years older and more in labor force. The gender inequality index highlights the status of women in 159 countries (UNDP 2016, 1-2). 
Figure 1: Gender inequality index

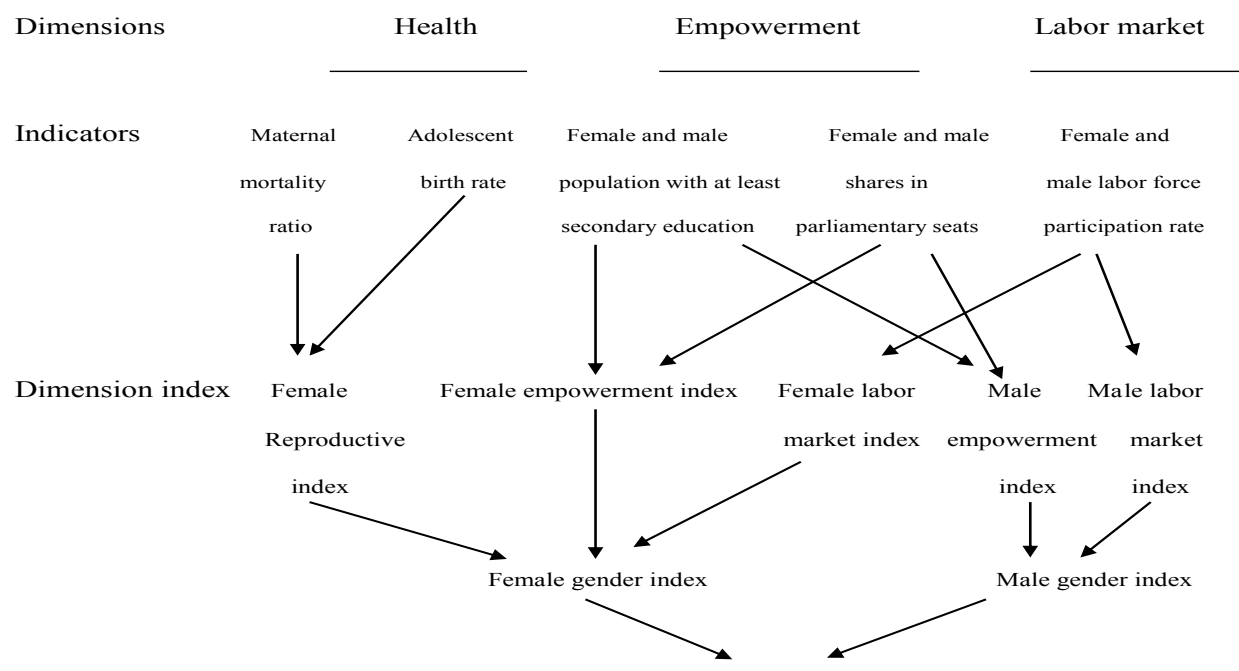

Gender inequality index (GII)

Source: UNDP 2016

This figure highlights a variety of dimensions, indicators, and dimensions index used to measure gender inequality index. In order to measure the dimension of health both maternal mortality ratio and adolescent birth rate indicators are used to determine the dimension index of the female reproductive index which used to calculate the female gender index. For the empowerment dimension, the indicators of female and male population, with at least secondary education, and female and male shares in the parliamentary seats index are used both to calculate the dimension index of female and male empowerment index. The third dimension is the labor market, the indicators of female and male labor force participation rate are used to determine the dimensions index of female and male labor market index. Then, on the one hand, the dimension index of female reproductive index, female empowerment index and female labor market index are used to determine the female gender index. On the other hand, the dimension index of male empowerment index and male labor market index are used to determine male gender index. After all, female gender index and male gender index are used to highlight the gender inequality index (UNDP 2016). 


\subsection{Gender Equality Index: "the glass half empty"}

A gender equality index is an approach used to measure and evaluate the status of women in European Union countries. The European Institute for Gender Equality (EIGE) was launched in 2010. Therefore, the European Council adopted Gender Equality Index in order to offer a new measure for assessing and interpreting the complexity of gender equality in the European Union over time. The European Institute for Gender Equality used the gender equality index as a composite indicator to presents the scores of Member states in terms of gender equality for the years 2005, 2010 and 2012. The European Institute for Gender Equality used six core domains and two satellite domains to evaluate gender equality in European Union states which are work, money, knowledge, time, power, health, violence and intersecting inequalities. This measure of domains and satellite show that the European Union was half-way toward equality (EIGE 2015, 9).

Figure 2: The eight domains of the gender equality index
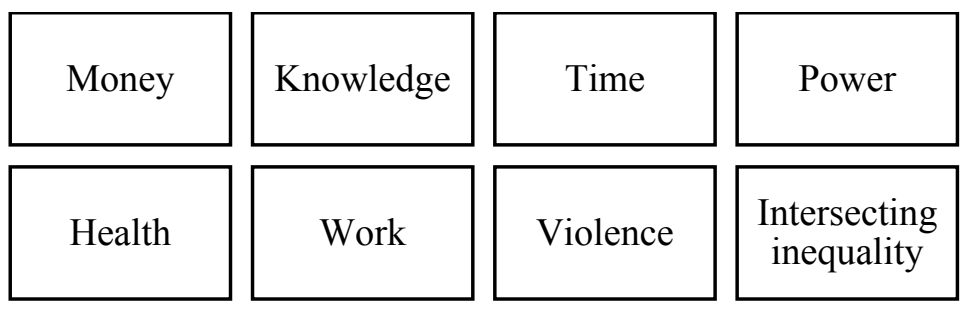

Source: EIGE, 2015, 12 (Gender Equality Index 2015 Measuring gender equality in the European Union 2005-2012)

Each domain of the six core domains is divided into sub-domains. In the domain of money statistic made to determine the indicators of financial resources and statistic situation. The domain of knowledge covers the attainment segregation and lifelong learning indicators. The time domain is subdivided into economic activity, care activities, and social activities. In the domain of power political, economic and social power are measured. In the domain of health three subdomains are measured which are status, behavior, and access. The domain of work is divided into three subdomains which are participation, segregation, and quality of work (EIGE 2015, 12).

The gender equality index used data from different sources such as Eurostat, Eurofound and DG Justice. All available data were used to calculate the gender equality index by using a solid analysis called principal component analysis (EIGE 2015, 13). 


\subsection{The Global Gender gap index (GGI): "the glass half full”}

The World Economic Forum was established in 1971 in Geneva. It is using the Global Gender Gap Index as a tool to measure the gender equality in 145 countries. The Global Gender Gap Index was created in 2006.For measuring gender gaps it uses four key areas indicators which are: health, economy politics, and education. Based on these criteria, they ranked countries in order to spread awareness among people in the whole world. These quantitative analyses are used to reduce gender gap and promote for equity and parity (World Economic Forum 2015).

Table 1: Structure of the Global Gender Gap Index

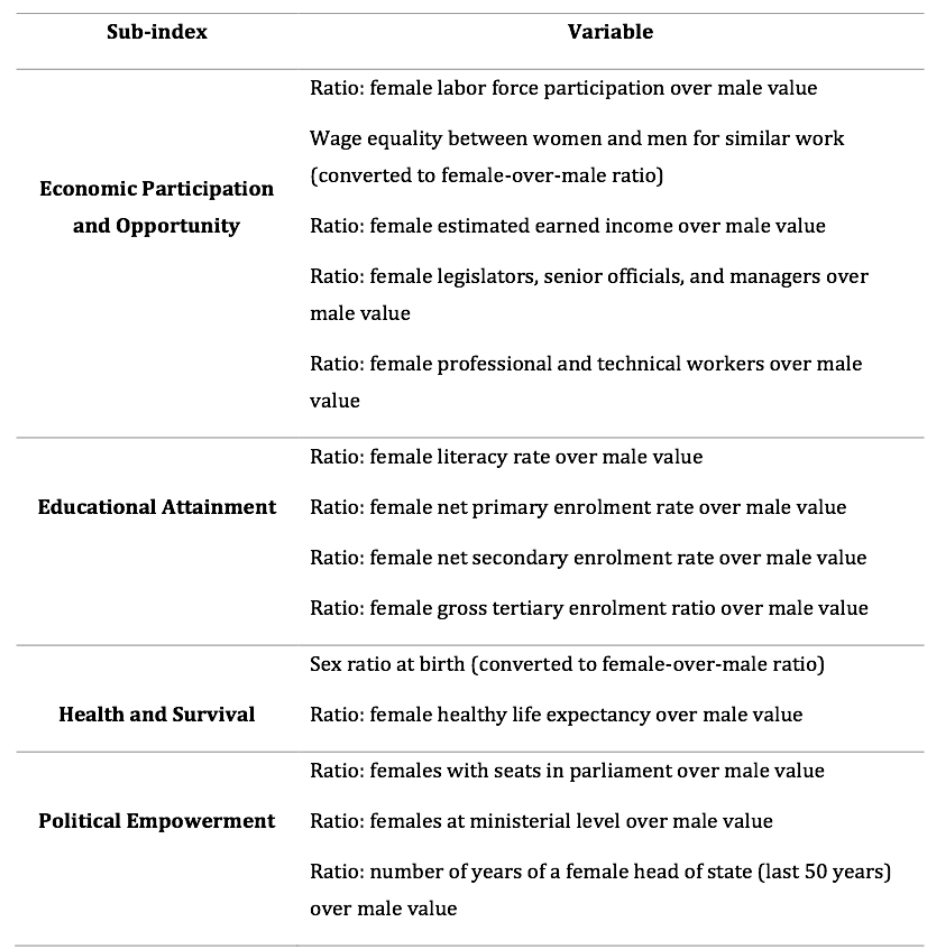

Source: World Economic Forum 2015, 5 (The Global Gender Gap Report 2015) 
The Global Gender Gap Index quantifies the countries according to the outcomes and not to the inputs which displys the tools such as rights, policies, tradition or custom etc. In all sub-indexes, the highest score is (1) which means equality and the lowest is (0) which means inequality (World Economic Forum 2015).

\section{The Status of women in Tunisia}

I choose the Global Gender Gap Index approach for analysing the status of women according to four key areas which are: economic participation and opportunity, educational attainment, health and survival and political empowerment.

\subsection{Tunisian women in education}

Enormous efforts to encourage Tunisians to enroll at schools and Universities have been made, mainly through imposing compulsory education up to 16 years children and maintain an equal access to all Tunisians to education by eliminating all forms of discrimination (Tunisia Constitution 2014).

\section{Education right}

In recent years, women in Tunisia have continued the positive trajectory in terms of education. The Tunisian law strongly acquires an education for both girls and boys. According to the article 39 of the constitution

"Education is mandatory until the age of sixteen. The State shall guarantee the right to free public education at all stages and shall seek to provide the necessary means to achieve a good quality of education, teaching and training, as it shall work to embed youth in their Arab-Islamic identity and national belonging, and to strengthen and promote the Arabic language and expand its usage, and openness to foreign languages and human civilizations, and spreading the culture of human rights" (Tunisia Constitution 2014, 13).

Since the fifties, the access to schools and universities increased. In fact, education became compulsory until the age of 16 . According to the 1956 census, $84.7 \%$ of the Tunisian people aged more than ten years old were illiterate. Therefore, illiterate men represented $74.5 \%$ of the population and illiterate women represented $96 \%$. Based on the 2004 census, the illiteracy rate decreased to become $22.9 \%$. Illiterate men represented $14.8 \%$ and $31.1 \%$ of illiterate women. In 2007 census, in primary schools, $95.5 \%$ of boys have enrolled in full-time primary education and the percentage of girls 
enrolled in primary school represented $96.7 \%$ which is higher than boys. The literacy rate of Tunisian aged between 15 and 24 had increased to become $97 \%$ of boys and $94.3 \%$ of girls. Not only at primary school but also at universities, the number of girls has been much higher than the number of boys. During the academic year 2007-2008, the number of female students enrolled in higher education universities represented 59,5\% and male represented $40.5 \%$. Indeed, the female has depicted the majority of students in many institutions and universities in Tunisia such as medicine, social science, and Arts. More than that, The National Program of Adult Education provide basic education for adults both in the urban and rural area and encouraged illiterate adults to join the basic courses. This program registered more attendance of women than men with a high percentage (Ben Salem $2010,14)$.

\subsection{Tunisian women in labor force}

There are two main elements that have played a crucial role in enhancing the status of women in Tunisia and facilitated for women its integration in labor force. The first element is the education and the second element is the demographic policy. In fact, education is one of the most important and profound societal projects in Tunisia. Also, the demographic policy has a fundamental effect on the social changes in the country since the independence.

\subsubsection{Economic rights}

The Tunisian law guarantees for women equal pay for equal work. According to the article 40 of the Tunisian constitution:

"Work is a right for every citizen, male and female. The State shall take the necessary measures to ensure work on the basis of competence and fairness. All citizens, male and female, have the right to adequate working conditions and to a fair wage" (Tunisia Constitution 2014, 13-14).

No one can deny the role of women in the economic development of Tunisia during several decades as employees and as businesswomen. Since years ago, Tunisian women have been able to participate in many different areas. They have succeeded to prove their capability to work in both inside and outside the home. 


\subsubsection{Equal opportunities}

The number of graduates from schools and universities in Tunisia is increasing every year, this number of graduates from university needs an increase in jobs offers. But, unfortunately, the labor market cannot absorb them. As a matter of fact, the gap between education output and employment opportunities became wide. To add more, the salary is the same for women as for men who work in public and it is stated in the constitution but not in private sector (Baliamoune 2012, 18).

Table 2: Evolution of the unemployment rate in Tunisia between 2005 and 2015

$\begin{array}{llllllllll}2006 & 2007 & 2008 & 2009 & 2010 & 2011 & 2012 & 2013 & 2014 & 2015\end{array}$

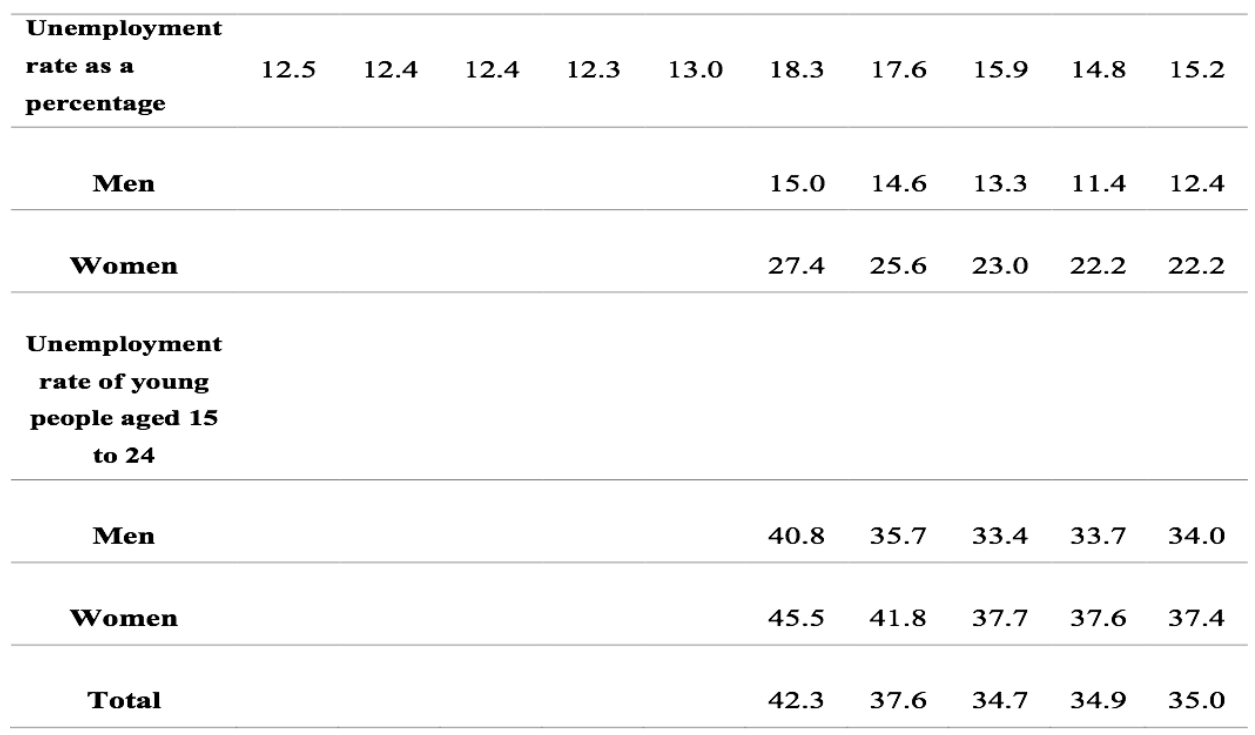

Source: Author/INS Tunisia (United Nation, Economic Commission for Africa, 2016)

The unemployment rate in Tunisia remains high in Tunisia. This table above shows the evolution of the employment rate in Tunisia between 2005 and 2015. After the revolution the unemployment rate increased from $12.3 \%$ in 2009 to became much higher with $18.3 \%$ in 2011, the revolution year, and reduced four years after the revolution to become $15.2 \%$ which is considered 
very high and higher than in 2009 (less than two years before the revolution).I am going to review briefly the unemployment rate of men and women in postrevolution. During the year 2011, the unemployment rate of men is high with $15.0 \%$ but it is higher among women with $27.4 \%$. Five years after the revolution, in 2015 the unemployment rate decreased but still considered high. In fact, for men, it becomes $12.4 \%$ and for women $22.2 \%$. When we examine the unemployment rate of young people aged between 15 years old and 24 years old, we notice that the rate of the unemployment of women is $45.5 \%$ and $40.8 \%$ in 2011 which decreased for both men and women to become $34.0 \%$ and $37.4 \%$. It is noticeable that parity in the unemployment is near to be achieved between man and women aged between the 15years old and 24 years old. This could be justified, for the reason, that men and women have relatively equal rights to have a job. Therefore, in Tunisia, there are national exams which must be taken after graduation in order to have a job in public sector. Women and men aged between 15years old and 24years old, the majority of them, are newly graduated from universities. In fact, those who succeed in the national exams, they have offered job in public sector regardless if they are women or men.

Accordingly, a deeper study of the status of women is needed in order to construct a useful research for the development of human resources. Therefore, the number of females at the Tunisian universities is higher than the number of men. This is considered as a cause for the low female employment rate comparing to male. Some Tunisian women, especially the uneducated women are fnding difficulties to get access to the labor market. In fact, they work in the agricultural sector within the family framework without pay or with other farmers with low income (comparing to men) or in factories and services sector in precarious conditions. The Tunisian government put many efforts to help women who work in agricultural sector. However, since the last decade no step has taken to enhance women' condition in that sector. Therefore, the government has introduced many social policies to overcome the precarious condition of women who work in illegal sectors without any social security. But, unfortunately, those policies remain unimplemented for a structural condition. "These structural conditions include the domestic market size, abundance or scarcity of labor, asset inequality and openness of the international economy". Some of the main reasons are manipulation of social insurance, economic crisis and the political dynamics (Sinha 2011, 198). 


\subsection{Tunisian women's political participation}

A special attention was devoted to Tunisian women's participation in political life. After the revolution, for the first time, Tunisian people became able to criticize the government freely. Therefore, women activists in polictics and the civil society such as Radhia Nasrawi, Maya Jribi, Mbarka Lebrahmi, Samia Abbou and many others in Tunisia played a crucial role for painting the country's democratic transition and political progress.

\subsubsection{Political empowerment}

After the revolution, women in Tunisia have offered more opportunities to be more active in political life and take part in social activities. Nevertheless, their participation still considered lower than the men's. In august 2016, a new government was inaugurated. Therefore, in this government, the number of women in the ministerial positions increased, six women were appointed as ministers: Hela chaikrouhou, the minister of Energy, Mining and Renewable Energy, Lamia Zribi, the minister of Finance, Samira Merai the minister of Health, Selma Elloumi Rekik, minister of Tourism and Crafts, Naziha Laabidi, minister of Women, Family, and Childhood, Majdouline Charni, minister of Youth and Sport (Tunisian government portal 2017).

\subsubsection{Political right, parity's system in the election}

In post-revolution, women in Tunisia actively participated in political life. Before 2011 election, women's organizations pronounced their demand for parity law. The High Authority of election set a rule which insist on all parties to apply the parity principle and to use alternation (man/woman) in the electoral lists for the election of October 2011 in order to promote gender equality and to provide women with more opportunities to participate in political domain. In Tunisia's new constitution, the article 46 state that:

"The State commits to protecting women's achieved rights and works to promote and develop them. The State shall guarantee equality of opportunity between men and women in the bearing of all responsibilities and in all fields. The State shall strive to achieve equal representation for women and men in elected councils. The State shall take the necessary measures to eradicate violence against women." (Tunisia Constitution 2014, 15)

Unfortunately, during the election of 2011, many parties did not respect the gender fully parity. Ironically, only the Islamist party Ennahdha applied the parity law in the electoral lists during the election. Accordingly, 42 out of 49 women from Ennahdha party were elected as representatives in the 
National Constituent Assembly out of 217 deputies, the total number of representatives in the National Constituent Assembly (Marks 2013, 2).

\subsubsection{Women in Parliament}

The 2011 election's results were a bitter disappointment for women in Tunisia. Despite the Tunisian constitution states for parity in the election, Tunisian women in parliament represent only 29 \% (CREDIF 2014, 10). In this context, Mighahed and Lack (2013) reported that:

"Half the candidates were women ... In all, more than 4,000 female politicians ran for office. And when the results were tallied, 27 percent of the seats went to women. It was far from an equal share ... but it was also far better than the international average; a mere 17 percent of seats in the U.S. Congress are held by women." (Mighahed and Lack 2013, 206-207)

It is right that the percentage is still above the world average which is $19 \%$ in the same year and the country still ranked the first in the Arab region, but it was unsatisfactory to achieve equity.

In 2014 election, the number of the seats of women in parliament increased to became $33,18 \%$. In this election, parties respect the parity law by inserting alternation (men/woman) in the electoral lists. In the National Constituent Assembly, women played a crucial role in debating and discussing articles in the constitution. They are representing their parties' opinion and ideologies. They have discussed many important topics such as the country's security, freedom of conscious, women's rights and many others. Despite their important role in the National Constituent Assembly, Tunisian women are facing many challenges and difficulties. One of the most challenges is to protect their rights (Amroussia, Hernandez, and Goicolea 2016, 190).

\section{Women's political challenges}

For the first time in Tunisia, five women applied as candidates for the presidential election of 2014, but only one entered the race of the election, the judge Khalthoum Kanou. The first one who applied was the politician and the activist Emna Mansour Karoui. The presence and the participation of women in the presidential election is very important to improve their status in political life. The candidates were pretty much sure that they will never win the election for several reasons. But, the aim of this application is symbolic, in order to encourage more women to participate in the political scene and to apply for leadership position. In this context, the political activist Kalthoum Kanou said: "Ma candidature est un message fort pour ceux qui cherchent à nous renvoyer plusieurs siècles en arrière" it means: my candidacy is a very 
good message for those who are trying to return us centuries of the past (translated by the author). By saying this, she would like to refer to the extremist Islamist who would like to manipulate women's rights based on religious discourse. Also, Torkiya Ben Khether, who is the Secretary General of the League of Tunisian Electors, was a candidate. In this context, she said: "Notre souci est la formation des femmes candidates pour une professionnalisation de l'action politique" it means that: our concern is the training of women candidates for being professional in political action (translated by the author). Accordinglly, her initiative to apply for the presidential election was to be an example to be followed by other women and to motivate Tunisian women to be courageous enough to perform in leadership positions (CREDIF 2014, 13-16).

\subsection{Tunisian women and health care}

Tunisia population increased from more than four million during the 1960's to become more than Ten million in 2007.This rise in the population rate has been combined with evolution in health care infrastructure, services, programs, and policies (Gataa 2011, 223).

\subsubsection{Healthcare right}

In Tunisia's law, women's reproductive health rights are protected. These laws are the first step to implementing reproductive health's policies, programs, and strategies which basically formulated on a legal framework. According to the article 38 of the constitution:

Health is a right for every person. The State shall guarantee preventive treatment and health care for every citizen and provide the necessary means to guarantee the safety and quality of health services. The State shall guarantee free health care for those without means and those with limited income. It shall guarantee the right to social assistance in accordance with the provisions set out by law" (Tunisia Constitution 2014, 13).

The new constitution guarantees for women the access to healthcare and provide them with the right to receive good services.

\subsubsection{Reproductive health}

Since 1961 women in Tunisia have been allowed to take contraceptives. And since 1973, the women have enjoyed the right to abort, under the family planning program. Since that time women in Tunisia have the right to access freely to abortion, have provided with contraceptives also have enjoyed other healthcare services for free in all hospitals. In addition to that, pregnant women are enjoying five prenatal consultations and two postnatal 
consultations in order to reduce maternal and neonatal mortality. More than that, another policy was implemented to protect and cured Tunisian women from breast cancer. For instance, the country is using a national cancer control plan. In 2010 the Ministry of Health in Tunisia expanded 15\% of the national budget to allocate and implement health care programs such as reproductive health care. But, in 2012, the total government expandenture on healthcare was only $7 \%$ of the national budget. This downfall of the expenditure in health care sector is because of the economic crisis in the country after the revolution. In 2014, the government expendenture on healthcare increased to become $10 \%$ of the whole budget of the country used to implement healthcare programs, but, it remains low percentage (Amroussia, Hernandez, and Goicolea 2016, 184).

Due to the family planning, Tunisia has succeded to control the fertility rate in the country. Also, it has achieved a balance between the economic and population growth. Following the independence of Tunisia, women in Tunisia have enjoyed a better status in the society. In fact, the strong link between the improvement of women status and the implementation of the family planning programme culminated the society toward modernity. The abolition of polygamy and repudiation, the education of women and many other key elements gave the Tunisian women a privileged position in the society and created more stability in the Tunisian families (Gataa 2011, 223-224).

\section{Conclusion}

Women in Tunisia gained same rights as men in education, labor force, political and health care domains. But in practice equality has been achieved only in education and health care. Despite of the legal documents guarantee for them equal rights, in political and economic participation, women still represent less than men in these domains. The question that should be asked in this context, either women are suffering from structural discrimination in these domains or other economic and cultural reason impede them from being active in these domains? To identify the structural discrimination, Fred L. Pincus (1996) states that: "structural discrimination refers to the policies of dominant race/ethnic/gender institutions and the behavior of the individual who implement these policies and control these institutions, which are race/ethnic/gender neutral in intent but have a differential and/or harmful effect on minority race/ethnic/gender groups" (Pincus 1996, 186). There is no evidence about structural discrimination of women's participation in labor force except the one which is about women who are working in agricultural sectors. Indeed, the government initiated some social 
policies to improve women situation in that sector, but, those policies had not been implemented. In political domain, the structural discrimination is obvious, as the manipulation of the parity law was crystal clear, women were excluded from political participation as many parties did not respect this law during the election of 2011. To sum up, women's economic and political participation remain low. Both sectors are strongly connected to eachother, so the first affect the second. I think, if the number of women increase in labor force, their number will increase also in leadership position in politics, to be president, prime minister or ministers. The different institutions of the state play a major role to increase women's representation in leadership position mainly in politics. These institutions should redistribute gender roles, to recognize women's work and to put more efforts to implement effecient policies in order to enhance more the status of women in political and economic domain.

\section{References}

Amroussia Nada, Hernandez Alison R and Goicolea Isabel. 2016. "Reproductive Health Policy in Tunisia: Women's Right to Reproductive Health and Gender Empowerment." Health and human right Journal 18 (2): 184-190.

Balliamoune-Lutz Mina. 2012. The making of gender equality in Tunisia and implications for development. World Development Report 2012. https://openknowledge.worldbank.org/bitstream/handle/10986/9228/W DR2012-0026.pdf?sequence=1\&isAllowed=y. Accessed May 9, 2017.

Ben Salem, Lilia. 2010. Women's rights in the Middle East and North Africa. New York: Freedom House.

Chanter, Tina. 2006. Gender: Key Concepts in Philosophy. London: MPG Books Ltd.

Connell, Raewyn. 1987. Gender and power: society, the person and sexual politics. Cambridge, Oxford: Polity Press.

CREDIF. 2014. Femme et elections: Les femmes peuvent-elles faire la différence?

Donaldson, Mike. 1993. "What Is Hegemonic Masculinity?" Theory and Society, Special Issue: Masculinities 22 (5): 643-657. 
European Institute For Gender Equality. 2015. Gender Equality Index 2015 Measuring gender equality in the European Union 2005-2012. http://eige.europa.eu/sites/default/files/documents/mh0215616enn.pdf.1 Accessed May 9, 2017.

Fraser, Arvonne S. 1999. "Becoming Human: The Origins and Development of Women's Human Rights.” Human Rights Quarterly 21 (4): 853-906. Johns Hopkins University Press.

Gataa Ridha. 2011. Women's Empowerment and Reproductive Health. UNDP: Volume 19: Experiences in addressing population and reproductive health challenges.

https://drive.google.com/file/d/0B-buqyoV0jpSa0N1aC1xaW9PR0E/view. Accessed June 9, 2017.

Hidasi Judit. 2016. Multiple identities of professional women in Taiwan. Budapest: Department of Social Communication and Media Studies Budapest Business School.

http://ccs.ncl.edu.tw/ccs2/files/research/Judit_Hidasi.pdf. Accessed June 9, 2017.

Jasmine Foundation. 2014. Constitution of the Tunisian Republic http://www.jasminefoundation.org/doc/unofficial_english_translation_of_tu nisian_constitution_final_ed.pdf. Accessed May 29, 2017.

Magi, Giovanna and Fabbri, Patrizia. 2008. Art and History: Tunisia. Florence: Casa Editrice Bonechi.

Marks, Monica. 2013. "Women's Rights before and after the Revolution.” In The Making of the Tunisian Revolution: Contexts, Architects, Prospects, edited by Nouri Gana, 224-251. Edinburgh: University Press.

Mighahed Nagwa and Lack, Stephen. 2013. "Women rights and gendereducational inequality in Egypt and Tunisia." In Education, Dominance, and Identity, edited by Diane B, 201-221. Napier and Suzanne Majhanovich. Istanbul: Sense Publisher.

Pincus, Fred L .1996. "Discrimination comes in many forms: Individual, Institutional, and Structural." American Behavioral Scientists 40 (2): 186-194. 
Roxton, Sandy (ed.). 2004. Gender Equality and Men: Learning from Practice. London: Oxfam GB.

Sinha, Sangeeta .2011. "Women's Rights: Tunisian Women in the Workplace." Journal of International Women's Studies 12 (3): 185-200.

The World Economic Forum. 2016. The Global Gender Gap Report 2016. http://estaticos.elmundo.es/documentos/2016/10/26/igualdad.pdf. Accessed June 9, 2017.

The World Economic Forum .2015. The Global Gender Gap Report 2015. http://www3.weforum.org/docs/GGGR2015/cover.pdf. Accessed June 9, 2017.

The Tunisian Government Portal. 2017. http://www.tunisie.gov.tn/index.php?option=com_content\&task=view\&id= 145\&Itemid=183\&lang=french. Accessed June 19, 2017.

United Nations Development Programme. 2016. Human Development Report 2016 Human Development for Everyone. New York: United Nations Development Programme.

http://hdr.undp.org/sites/default/files/2016_human_development_report. pdf. Accessed 19, 2017.

United Nations Development Programme.

http://hdr.undp.org/en/content/gender-inequality-index-gii. Accessed June 19, 2017.

United Nations, Economic Commission For Africa. 2016. Country profile 2016. http://www.uneca.org/sites/default/files/uploadeddocuments/CountryPro files/2017/tunisia_cp_eng.pdf. Accessed June 19, 2017.

United Nations Development Programme.

http://hdr.undp.org/en/content/gender-inequality-index-gii. Accessed June 9, 2017. 